\title{
A Quantitative Analysis of Development of Biomass Energy in Heilongjiang Province in China Based on GRA*
}

\author{
Zhen Hua \\ Harbin University \\ Harbin, China
}

\author{
Man Lu \\ Harbin University \\ Harbin, China
}

\begin{abstract}
China needs an enormous amount of energy to maintain the future economic developments while Heilongjiang province has the largest forest regions in China so that it has a huge potential of biomass energy resources to reduce the dependence on fossil fuels. This paper identifies the factors which are influencing development of biomass energy in Heilongjiang Province in China, uses GRA (Grey Relational Analysis) to analyze grey relation degree of the energy development in the past seven years (2011-2017). Meantime, it forecasts the grey relation degree in the following five years (2018-2022) by modeling grey system forecasting GM $(1,1)$ and then provides the countermeasures of developing biomass energy in Heilongjiang Province. It is useful for the application nationwide.
\end{abstract}

Keywords-biomass energy; GRA; China

\section{INTRODUCTION}

Each factor remains its significance for biomass development, however, there is no obvious linear relationships between those factors, the energy system is considered as a complex variable one, it lacks of the data in which biomass energy can be converted directly, and of which lacks of sufficient data and has its uncertainty. The grey system theory GRA (Grey Relational Analysis) uses a specific concept of information. It defines situations with no information as black, and those with perfect information as white. However, neither of these idealized situations ever occurs in real world problems. In fact, the situations between these extremes are described as being grey, hazy or fuzzy. Thus, grey relational analysis is adopted as the main tool for analyzing the development of the biomass in this paper.

\section{METHODOLOGY}

A grey system means that a system in which part of information is known and part of information is unknown, and with this definition, information quantity and quality form a continuum from a total lack of information to complete information - from black through grey to white. Since uncertainty always exists, one is always somewhere in the

*This paper is sponsored by Nation natural science foundation of China: research of China's coal supply scenarios forecasting and evaluation (2016GXS4D099); China Harbin University doctor research programme: a study on the strategy of biomass energy development in Heilongjiang Province based on grey system (HUDF2018107). middle, somewhere between the extremes, somewhere in the grey area. Grey analysis then comes to a clear set of statements about system solutions. ${ }^{1}$ Grey relational analysis (GRA) fundamental thought is between two systems, the degree of the correlation is defined as a measurement of the size of the correlation between the systems, their changes over time, or different objects.

The specific calculation steps of the grey relational analysis have shown as follows:

The referencing sequences are named as those referencing sequences which represent the features of the system behavior, those comparative sequences which influencing the system behavior and the data sequences which represent the features of the system behaviors. The data sequences a composed by those all the factors which can influence the system behavior, thus:

$\{\mathrm{X} 1(0) \quad(\mathrm{t})\}, \quad\{\mathrm{X} 2(0) \quad(\mathrm{t})\}, \ldots, \quad\{\mathrm{Xm}(0)(\mathrm{t})\}, \mathrm{t}=1,2, \ldots, \mathrm{N}$

As in (1), $\mathrm{N}$ is the length of the sequence, which is the amount number of the data, $\mathrm{M}$ means the amount number of the factors (variables).

The referencing sequences and comparative sequences mensionless should be dimensionless processed. Due to the different physical meanings existing between factors, the dimensions of the data are unlikely the same, thus, normally, we have to take data into dimensionless processing while grey relational analyzing.

To fine the coefficient of referencing and comparative sequences $\zeta(\mathrm{Xi})$, correlation degree is essentially the difference between the geometric shapes of the curves, so the difference between curves can be considered as the main measurement of correlation degree. Each referencing sequence $\mathrm{X} 0$ has a certain comparative sequences

$$
r_{\text {oi }}=\frac{1}{N}+\sum_{k=1}^{N} L_{\text {oi }}(k)
$$

Liu, Sifeng; Yang, Yingjie; Forrest, Jeffrey (2017). Grey Data Analysis. Methods, Models and Applications. Singapore: Springer. ISBN 978981-10-1841-1. 
$\mathrm{Xi}, \mathrm{X} 2, \ldots \mathrm{Xn}$, the correlation coefficient $\xi(\mathrm{Xi})$ of referencing sequences and comparative sequences at each moment (each point on the curve) can be calculated as followed: $\zeta$ is the identification coefficient which has $0<\zeta$ $<1 . \Delta \min$ is the minimum second order difference, and which has $0<\zeta<1$. $\Delta \max$ is the maximum second order difference. (P79)

$$
L_{\text {oi }}(k)=\frac{\Delta_{\min }+\rho \Delta_{\max }}{\Delta_{0 i}(k)+\rho \Delta_{\max }}
$$

To find the correlation degree $\mathrm{r}_{\mathrm{oi}}$ : because the correlation coefficient is the correlation values of each time point on the referencing and comparative sequences, the number of the coefficient is greater than 1, and due to the information decentralization, it is not convenient for overall comparison, therefore, it is necessary to obtain an average value as the quantity of the correlation degree of referencing and comparative sequences.

$$
r_{\text {oi }}=\frac{1}{N} \sum_{k=1}^{N} L_{\text {oi }}(k)
$$

Ranking the correlation degrees: the correlation degree of factors not only describes the values of correlation degree but also describes its rankings. Now, put the subsequences correlation degrees in order, those are related to the principal sequences, so the relational order is $\{x\}$, which reflects the "better or worse" relationship of subsequences related to the principal sequences. If $\mathrm{r}_{\mathrm{oi}}>\mathrm{r}_{\mathrm{oj}}$, then, it has $\{\mathrm{x} 0\}$ is better than $\{\mathrm{xj}\}$ to the same principal sequence.

\section{DATA COLLECTION}

The paper focuses on the demarcation of the development factors which influencing biomass energy in Heilongjiang Province, and this paper collects the data reckoning of logging residue, tending felling, residua processing as the predicted data of biomass energy. And this paper collects energy consumption in Heilongjiang Province, low grade forest, saline and alkaline land modification area, the number of rural technical personnel, the average wage of rural employees, the number of laid-off workers awaiting resettlement from the year of 2011 to 2017.

TABLE I. The Chart of Biomass Energy Development Factors In HeIlongJiang Province (2011-2017)(1)

\begin{tabular}{|l|l|l|l|}
\hline \multicolumn{1}{|c|}{ year } & \multicolumn{1}{|c|}{$\begin{array}{c}\text { Energy consumption } \\
\text { (TCE) }\end{array}$} & \multicolumn{1}{c|}{$\begin{array}{c}\text { Volume of biomass } \\
\text { (TCE) }\end{array}$} & $\begin{array}{c}\text { rural technical } \\
\text { personnel(capita) }\end{array}$ \\
\hline 2011 & 8730.96 & $2,576,854$ & 69917 \\
\hline 2012 & 9377.14 & $2,763,232$ & 68482 \\
\hline 2013 & 9979.39 & $2,986,905$ & 71395 \\
\hline 2014 & 10466.70 & $3,179,895$ & 71851 \\
\hline 2015 & 11233.51 & $3,268,581$ & 69862 \\
\hline 2016 & 12118.50 & $3,308,656$ & 69783 \\
\hline 2017 & 12757.80 & $3,397,688$ & 71973 \\
\hline
\end{tabular}

TABle II. The Chart of Biomass Energy Development Factors In HeIlongJiang Province (2011-2017)(2)

\begin{tabular}{|l|l|l|l|}
\hline year & modification area $\left(\mathbf{h m}^{\mathbf{2}}\right)$ & $\begin{array}{c}\text { average wage of rural employees } \\
\text { (yuan/capita annual) }\end{array}$ & $\begin{array}{c}\text { laid-off workers awaiting } \\
\text { resettlement }\end{array}$ \\
\hline 2011 & 9130 & 4782 & 28436 \\
\hline 2012 & 7558 & 5360 & 13949 \\
\hline 2013 & 10886 & 6392 & 21865 \\
\hline 2014 & 7962 & 6686 & 17980 \\
\hline 2015 & 8846 & 7030 & 11955 \\
\hline 2016 & 11048 & $3,308,656$ & 12486 \\
\hline 2017 & 12289 & $3,397,688$ & 11384 \\
\hline
\end{tabular}

\section{The CORRElation Degree ANALysis of Biomass DEVELOPMENT}

This part chose the volume of biomass energy as the referencing sequences, and the energy consumption, energy supply, low grade forest, saline and alkaline land modification area $\left(\mathrm{km}^{2}\right)$, and rural technical personnel (capita) as the comparative sequences, the correlation degree between development of Heilongjiang Province biomass and other factors from the year of 2011 to 2017 can be gained by using DPS9.50 data processing system (see "Table III"). 


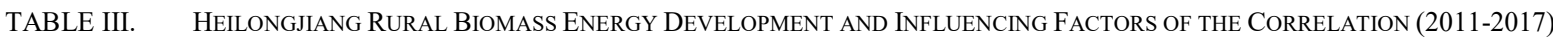

\begin{tabular}{|l|l|l|l|l|l|}
\hline $\begin{array}{c}\text { Volume of } \\
\text { biomass energy }\end{array}$ & \multicolumn{1}{|c|}{$\begin{array}{c}\text { Energy } \\
\text { consumption }\end{array}$} & $\begin{array}{c}\text { rural technical } \\
\text { personnel }\end{array}$ & $\begin{array}{c}\text { modification } \\
\text { area }\end{array}$ & $\begin{array}{c}\text { average wage of } \\
\text { rural/forestry } \\
\text { employees }\end{array}$ & $\begin{array}{c}\text { laid-off workers } \\
\text { awaiting } \\
\text { resettlement }\end{array}$ \\
\hline $\begin{array}{l}\text { Degree of } \\
\text { correlation }\end{array}$ & 0.80251 & 0.88747 & 0.69053 & 0.84541 & 0.61273 \\
\hline
\end{tabular}

We can see from "Table III", correlation degree $\xi 2>\xi 4>\xi 1>\xi 3>\xi 5$, in the development of biomass energy, the important outstanding factor is the development of biomass technology; second important factor is that people working in the agricultural system are urgently improving their quality of life; the third important factor is the influence of energy consumption demand on biomass energy; and the forth factor is that biomass development spacing and employment of surplus labor in rural areas. Thus, it can be seen that primary factor is the R\&D and utilization of biomass technology, and the meantime, the conflicts between energy consumption and energy supply is becoming more outstanding ever than before, new type of energy and new technology are urgently needed to ease the conflict. The policy of "returning the grain plots to forestry "implementation makes the low-grade forest; saline and alkaline land modification area is greater than before which can be considered as a great opportunity to develop Heilongjiang biomass energy. Overall, before the year of 2011, the development of biomass energy in Heilongjiang Province was in demand, but not urgently.

The forecasting factors of influencing biomass energy development in Heilongjiang Province: this part focuses on forecasting dynamic factors which influencing the development of the Heilongjiang biomass energy. And because Gray System Theory is the method which has been used to research uncertain problem lack of data and information, and which is suitable for biomass energy forecasting, and grey GM $(1,1)$ model is adopted, which can be seen in "Table IV" "Table V".

TABlE IV. Influnencing Factors of Forest Biomass Energy DeVelopment in Heilongjiang Province(1)

\begin{tabular}{|l|l|l|l|}
\hline \multicolumn{1}{|c|}{ year } & \multicolumn{1}{c|}{$\begin{array}{c}\text { Energy consumption } \\
\text { (TCE) }\end{array}$} & $\begin{array}{c}\text { Volume of biomass } \\
\text { (TCE) }\end{array}$ & $\begin{array}{c}\text { rural technical } \\
\text { personnel(capita) }\end{array}$ \\
\hline 2018 & $11,853.00$ & $2,897,790$ & $66,859.7$ \\
\hline 2019 & $11,955.00$ & $2,938,503$ & $66,803.5$ \\
\hline 2020 & $12,126.00$ & $2,982,473$ & 68,960 \\
\hline 2021 & $12,280.00$ & $3,137,280$ & 70,082 \\
\hline 2022 & $12,440.00$ & $3,838,960$ & 88,228 \\
\hline
\end{tabular}

TABLE V. Influnencing Factors of Forest Biomass EnERgy DeVElopment in HeILONGJIANg Province(2)

\begin{tabular}{|c|c|c|c|}
\hline year & modification area(hm²) & $\begin{array}{l}\text { average wage of rural/forestry } \\
\text { employees (yuan/capita annual) }\end{array}$ & $\begin{array}{c}\text { laid-off workers awaiting } \\
\text { resettlement(capita) }\end{array}$ \\
\hline 2018 & $14,288.2$ & $8,026.2$ & $4,807.8$ \\
\hline 2019 & $15,762.9$ & $8,662.3$ & $5,607.2$ \\
\hline 2020 & $16,153.5$ & $9,108.7$ & 5083.5 \\
\hline 2021 & $16,862.2$ & $9,766.8$ & $4,363.2$ \\
\hline 2022 & $18,670.4$ & $10,438.5$ & $3,776.7$ \\
\hline
\end{tabular}

This part choses the volume of biomass energy as the referencing sequences, and the energy consumption, energy supply, low grade forest, saline and alkaline land modification area $\left(\mathrm{km}^{2}\right)$, and rural technical personnel (capita) as the comparative sequences, the correlation degree between development of Heilongjiang Province biomass and other factors from the year of 2018 to 2022 can be gained by using DPS9.50 data processing system (see "Table VI").

TABLE VI. HEILONGJIANG RURAl BIOMASS ENERGY DEVELOPMENT AND INFLUENCING FACTORS OF THE CORRELATION (2018-2022)

\begin{tabular}{|l|l|l|l|l|l|}
\hline $\begin{array}{c}\text { Volume of } \\
\text { biomass energy }\end{array}$ & \multicolumn{1}{|c|}{$\begin{array}{c}\text { Energy } \\
\text { consumption }\end{array}$} & $\begin{array}{c}\text { rural technical } \\
\text { personnel }\end{array}$ & \multicolumn{1}{|c|}{$\begin{array}{c}\text { modification } \\
\text { area }\end{array}$} & $\begin{array}{c}\text { average wage of } \\
\text { rural/forestry } \\
\text { employees }\end{array}$ & $\begin{array}{c}\text { laid-off workers } \\
\text { awaiting } \\
\text { resettlement }\end{array}$ \\
\hline $\begin{array}{l}\text { Degree of } \\
\text { correlation }\end{array}$ & 0.4856 & 0.6384 & 0.3286 & 0.2482 & 0.5859 \\
\hline
\end{tabular}

It can be also seen from "Table VI", and the correlation degree which is satisfied that $\xi 2>\xi 5>\xi 1>\xi 3>\xi 4$, in the development of biomass energy, an important outstanding change is that the factor of "the number of laid-off workers awaiting resettlement "ranks the second place instead of the fifth last time, and which shows after the year of 2012, forestry and rural natural resources are protected efficiently, however, due to the restriction of harvesting woods, the traditional logging, processing industry and transportation which are not up to new standard are forced to shut down according to the relevant policies or laws, so that it make the Rural surplus labor force increases, and the income of the rural and forestry employees had declined sharply, some of them are not even able to maintain the basic standard of living. Then the energy 
consumption ranks unchanged (3rd place), and that shows that the problem of unreasonable energy structure remains unsolved which can be an obstacle to the economic development of rural and forestry areas. The average wage of the rural and forestry employees ranks the fifth rather than 2nd place previously, the current correlation degree is $\xi 4=0.2482$ which shows that the factor has not obvious influence on biomass development of Heilongjiang Province currently, the rural and forestry technical personnel are able to dress warmly and eat their fill comparing with the laid-off workers awaiting resettlement. Meanwhile, that shows the rural and forestry employees commonly have poor insufficient awareness about the biomass development can benefit Heilongjiang Province in all aspects, it can be seen form the two correlation analysis', the R\&D in technology of biomass is one of the most crucial factor in development of biomass energy in Heilongjiang Province.

\section{CONCLUSION}

The demand features of the biomass energy in Heilongjiang can be recognized through the factors analysis of the biomass energy development and the trend forecast of the energy analysis in the near future in Heilongjiang Province. And it can be seen from the result of the analysis that there is a great demand of biomass energy, no matter with the purpose of adjustment the current energy structure in the macro level or with the purpose of solving the rural and forestry surplus labor force, or with the purpose of improving the rural and forestry living standard. Especially in the situation that the timber production has been greatly reduced, the current ways of traditional heating and cooking which are mainly relying on the timber production are necessary to change urgently, so that it is helpful for controlling wanton felling trees, avoiding forest fire hazards, and protecting the rural forestry resources. Thus, development of the biomass energy is one of the most efficient ways of adjusting energy structure and improving people's living standard in Heilongjiang Province.

It can be seen from the forecast of the biomass energy volume in Heilongjiang Province, the sustainable development capability has risen steadily for years in rural and forest areas of Heilongjiang Province. After the "renewable energy law" established in 2006, during the decade after 2006, the biomass energy has developed faster than ever before, it can also be seen that with the supplementary laws, administrative regulations and sectorial rules established, the utilization of surplus materials from rural and forestry will be welldeveloped in the next few years, and it has the wide practical prospect and huge developing potential. The agricultural and forestry biomass resources can be BMF (Biomass Molding Fuel) after fabrication which has its advantage of reduction of energy consumption in the process of production, thus, carrying out its production campaign at scale in Heilongjiang Province will have a brilliant future.

As can be seen in the above two analysis, the R\&D of biomass technology has great far-reaching significant influence on local agriculture and forestry development. The rapid development of biomass energy needs advanced technology, and the biomass technology needs continuous innovation which is one of the most crucial factors. And according to the former analysis results, it has the relatively mature biomass technology in Heilongjiang Province.

Developing biomass energy in Heilongjiang Province is to meet the demand of rural and forestry people increasing living standard, which can also improve the structure of energy consumption, additionally, the relatively mature biomass technology and fruitful biomass resource are the solid foundation of developing biomass energy, and the future of biomass in Heilongjiang is promising.

\section{REFERENCES}

[1] Lv. Chun. Research on renewable energy development based on Grey relational analysis. Mathematics in practice[J]. 2018.03. vol.48.

[2] J. Moran. Use of Grey Relational Analysis Assess and Optimize Small Biomass Boilers. Fuel Processing Technology[J]. Vol.87 Issue 2. January 2006. P123-127.

[3] NH. Wang. Correlation analysis of relationship of economic development and carbon dioxide emission in different period. Environmental Science and Technology[J]. 2011, 34(6): P191-194.

[4] YZ. Zhang. The development of China's biomass power industry under feed-in tariff and renewable portfolio standard: A system dynamics analysis[J]. Energy. Vol.139 2017(11): P947-961.

[5] Yanjun Su. Spatial distribution of forest aboveground biomass in China: Estimation through combination of spaceborne lidar, optical imagery, and forest inventory data[J]. Remote Sensing of Environment Vol.173, 2016, P187-199.

[6] Zhang Caiqin. Biomass and biofuels in China: Toward bioenergy resource potentials and their impacts on the environment[J]. Renewable and Sustainable Energy Reviews. 2017.8.

[7] Tao Qibo. Correlation Analysis of Seed Yield with Photosynthetic Rate and Biomass of Cleistogenes songorica Leaves in Different Position During Seed Development[J]. Acta Agrestia Sinica. 2017-03 